\title{
Sacral bone cyst treatment resulting in paraplegia
}

\author{
Neil Keshvani, ${ }^{1}$ Arjun Gupta, ${ }^{1}$ Corbin Eule, ${ }^{1}$ Navid Sadeghi ${ }^{1,2}$
}

${ }^{1}$ Department of Internal Medicine, University of Texas Southwestern, Dallas, Texas, USA

${ }^{2}$ Department of Hematology and Oncology, University of Texas Southwestern, Dallas, Texas, USA

\section{Correspondence to}

Dr Navid Sadeghi,

Navid.Sadeghi@

UTSouthwestern.edu

Accepted 4 January 2018

\section{DESCRIPTION}

A 50-year-old man with a stage 1 solitary right sacral plasmacytoma complained of a sharp, burning lower back pain with radiation into his right lower extremity which worsened with movement. He had initially undergone localised radiation therapy, but the pain did not resolve. Postradiation CT-guided biopsy showed persistence of malignant plasma cells, and he then underwent seven cycles of VRD (dexamethasone, lenalidomide and bortezomib) chemotherapy. After chemotherapy, an 18-fluorodeoxyglucose-positron emission tomography/ CT scan showed a new area of uptake in the right sacral ala near the initial plasmacytoma. A subsequent CT-guided biopsy was non-diagnostic, and repeat imaging at the time of presentation showed no interval growth. The lesion was believed to be a residual cyst with inflammatory changes from radiotherapy. Examination revealed no neurological deficits. The patient's pain was thought to be secondary to the cyst (figure 1) and was not relieved with physical therapy, duloxetine or opioid pain medication. He was referred to orthopaedics, who recommended cyst aspiration and bone grafting.

In the operating room under fluoroscopy, a trephine was placed into the right sacral bone cyst. Bloody fluid was aspirated from the cyst, and the resulting cavity was injected with calcium sulfate-calcium phosphate composite bone graft (PRO-DENSE, Wright Medical Technology, Arlington, Tennessee, USA). Two hours after his procedure, the patient began to experience severe back pain, lower extremity weakness, and a loss of bladder and bowel function. A CT scan demonstrated intraspinal and intradural extension of a bone substitute material occupying the entirety of the spinal canal through L1 with resultant effacement of the nerve roots of the cauda equina and compression of the terminal cord (figure 2). On physical exam, his temperature was $36.2^{\circ} \mathrm{C}$, heart

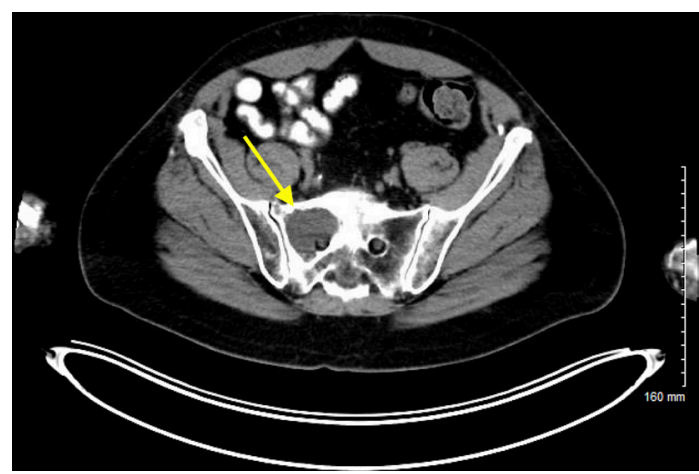

Figure 1 CT pelvis showing the right sacral cyst with inflammatory features.

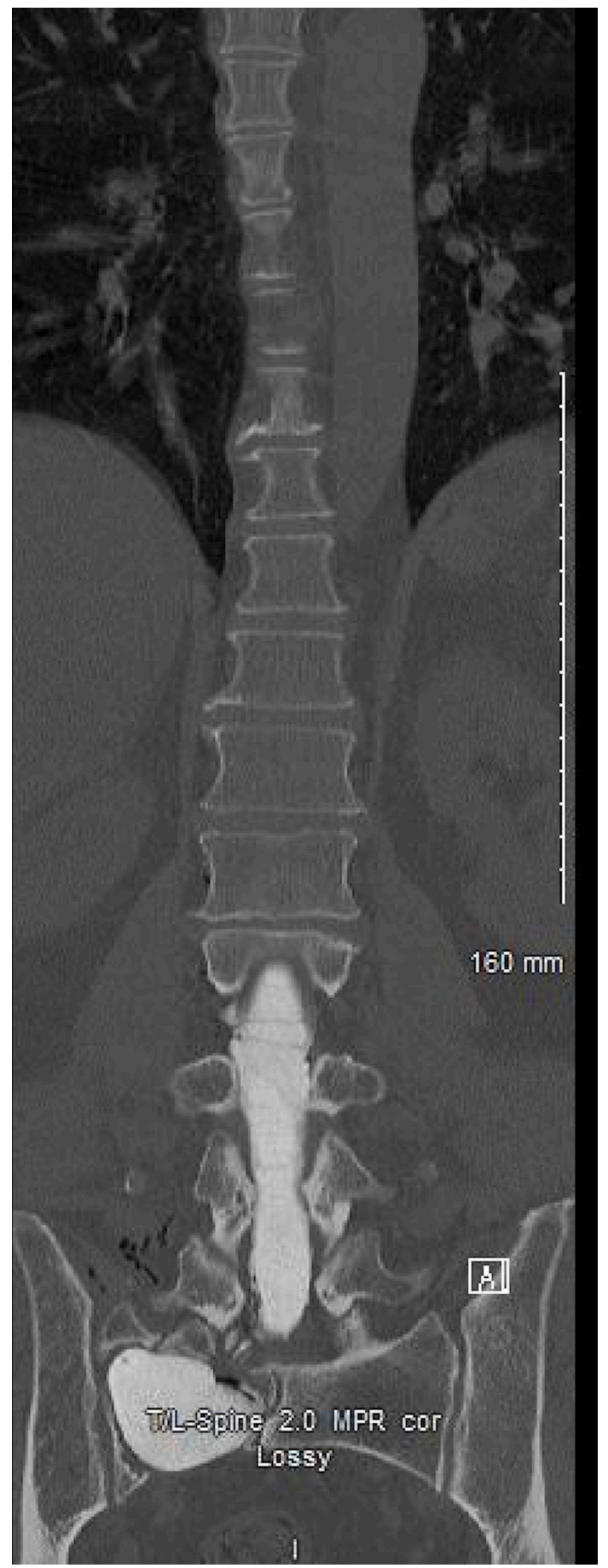

Figure $2 \mathrm{CT}$ thoracic spine showing bone graft material casting the entire cauda equina resulting in paraplegia.

rate was $97 / \mathrm{min}$, respiratory rate was $20 / \mathrm{min}$ and blood pressure was $146 / 93 \mathrm{~mm} \mathrm{Hg}$. He had near-complete sensory loss below the umbilicus and complete loss of motor function in his lower extremities. Neurosurgery was consulted and 


\section{Patient's perspective}

"When they talk about the surgery with you, you never think anything is going to happen to you. My life is completely different now."

\section{Learning points}

- The treatment of choice for a solitary bone plasmacytoma is radiation therapy, but postradiation residual cysts may result and become a source of pain and debility. ${ }^{3}$

- Bone graft substitutes are intended to create ideal environments for bone regeneration. Common adverse effects include both local and deep infections and fractures.

- We present a rare adverse outcome from graft injection causing complete paraplegia after graft extension into the spinal canal.

recommended emergent laminectomy and intradural exploration before the material cured after 24 hours. However, they believed that the patient would be unable to regain meaningful neurological function, and the patient declined operative intervention. Four weeks later, he has complete paraplegia with no sensation below L1 on the right and L2 on the left side. He is now legally disabled and has significant trouble with activities of daily living and mobility. Cyst aspirate pathology was negative for malignant cells.

Bone graft substitutes promote bone defect repair by providing a scaffold for bone growth on their surface. The injected substitute is eventually resorbed by the body, with newly deposited bone remaining in place. As such, they are used to treat open bone voids and gaps secondary to cysts, tumours and trauma-related osseous defects. Previously published studies have reported superficial and deep infections and postoperative fractures as adverse effects from their use. However, more serious adverse effects such as intraspinal bone leakage have been observed with polymethyl methacrylate bone cement. ${ }^{12}$ This case presents a rare, debilitating adverse effect of complete paraplegia after intraspinal extension of injected bone graft intended for symptomatic relief.

Contributors NK, AG, CE and NS made substantial contributions to conception or design of the work, or the acquisition, analysis or interpretation of data for the work: drafting of the work or revising it critically for important intellectual content; gave final approval of the version to be published; and agree to be accountable for all aspects of the work in ensuring that questions related to the accuracy or integrity of any part of the work are appropriately investigated and resolved.

Funding This research received no specific grant from any funding agency in the public, commercial or not-for-profit sectors.

Competing interests None declared.

Patient consent Obtained.

Provenance and peer review Not commissioned; externally peer reviewed.

(C) BMJ Publishing Group Ltd (unless otherwise stated in the text of the article) 2018. All rights reserved. No commercial use is permitted unless otherwise expressly granted.

\section{REFERENCES}

1 Urban RM, Turner TM, Hall DJ, et al. Increased bone formation using calcium sulfatecalcium phosphate composite graft. Clin Orthop Relat Res 2007:459:110-7.

2 Teng MM, Cheng H, Ho DM, Dm H, et al. Intraspinal leakage of bone cement after vertebroplasty: a report of 3 cases. AJNR Am J Neuroradiol 2006;27:224-9.

3 Kilciksiz S, Karakoyun-Celik O, Agaoglu FY, et al. A review for solitary plasmacytoma of bone and extramedullary plasmacytoma. ScientificWorldJournal 2012;2012:1-6.

Copyright 2017 BMJ Publishing Group. All rights reserved. For permission to reuse any of this content visit

http://group.bmj.com/group/rights-licensing/permissions.

BMJ Case Report Fellows may re-use this article for personal use and teaching without any further permission.

Become a Fellow of BMJ Case Reports today and you can:

- Submit as many cases as you like

- Enjoy fast sympathetic peer review and rapid publication of accepted articles

- Access all the published articles

- Re-use any of the published material for personal use and teaching without further permission

For information on Institutional Fellowships contact consortiasales@bmjgroup.com

Visit casereports.bmj.com for more articles like this and to become a Fellow 